\title{
PENGGUNAAN IDIOM BAHASA KEI PADA RANAH ADAT OLEH MASYARAKAT DESA FAAN, KECAMATAN KEI KECIL
}

\author{
Ana Maria Risye Renwarin \\ Romilda Arivina da Costa \\ Universitas Pattimura \\ e-mail: annaelkanew@gmail.com; ronaromilda70@gmail.com
}

\begin{abstract}
Abstrak: Bahasa yang terbentuk dalam tuturan atau teks merupakan wahana yang memuat pengetahuan atau budaya kehidupan para penutur bahasa tersebut. Kadang-kadang dengan satu atau dua buah kata saja, seseorang dapat menyampaikan sejumlah ide yang kaya makna. Bentuk klasik yang lazim digunakan oleh suatu masyarakat etnis adalah idiom. Oleh masyarakat Desa Faan sebagai penutur bahasa Kei, bentuk ini paling intens digunakan pada ranah adat. Makanya, melalui wawancara mendalam dengan beberapa pelaku adat, juga observasi, dan penelusuran dokumentasi, data-data menyangkut idiom dikumpulkan. Selanjutnya, dengan analisis deskriptif kualitatif tampak bahwa masyarakat Desa Faan cenderung menggunakan idiom penuh dan idiom sebagian dalam fungsinya secara representasional, konatif, poetik, dan metalinguistik.
\end{abstract}

Kata Kunci: idiom, ranah adat, fungsi, bentuk, makna 


\title{
THE USE OF KEI LANGUAGE IDIOM IN THE TRADITION DOMAIN
} BY THE FAAN VILLAGE COMMUNITY, KEI KECIL SUBDISTRICT

\author{
Ana Maria Risye Renwarin \\ Romilda Arivina da Costa \\ Pattimura University \\ e-mail: annaelkanew@gmail.com; ronaromilda70@gmail.com
}

\begin{abstract}
Language that developed in speech or text is a vehicle that contains knowledge or culture of the speakers. Sometimes with only using one or two words, a person can express a number of ideas that are rich in meaning. The classic form which is commonly used by an ethnic society is idiom. In Faan Village community as speakers of the Kei language, this form is most intensely used in the domain of tradition. The data related to idioms are collected through in-depth interviews with several traditional actors, as well as observations and documentation searches. Furthermore, the data had been analyzed by using a qualitative descriptive analysis. The results show that the people in Faan Village tend to use full idioms and partial idioms in their functions in representational, conative, poetic, and metalinguistic manner.
\end{abstract}

Keywords: idiom, tradition domain, function, form, meaning 


\section{A. PENDAHULUAN}

Bahasa merupakan ciri identitas suatu bangsa. Melalui bahasa, orang dapat mengidentifikasi kelompok masyarakat, bahkan dapat mengenal perilaku dan kepribadian masyarakat penuturnya karena bahasa merupakan alat untuk mengekspresikan gagasan, pikiran, dan ideologi. Oleh sebab itu, masalah kebahasaan tidak terlepas dari kehidupan masyarakat penuturnya.

Menurut Kridalaksana (2008:24) bahasa didefinisikan sebagai sistem lambang bunyi yang arbitrer, yang digunakan oleh masyarakat untuk bekerjasama, berinteraksi, dan mengidentifikasikan diri. Artinya, berkomunikasi adalah penyampaian ide, pikiran, dan keinginan dari komunikator kepada komunikan, baik secara lisan maupun tertulis sehingga dapat dimengerti dan dipahamiseperti yang dimaksudkan oleh komunikator.

Pengertian dan pemahaman antara kedua pihak dapat terjadi karena penyampaian ide, pikiran, dan keinginan melalui bahasa seyogyanya adalah penyampaian makna-makna. Bentuk bahasa yang digunakan untuk berkomunikasi bisa sangat bervariasi, mulai dari kata sampai wacana. Kadang-kadang dengan bermodalkan satu atau dua buah kata saja, seseorang dapat menyampaikan sejumlah ide yang kaya makna. Misalnya, gabungan kata otak udang tidak dihubungkan dengan bagian tubuh udang (salah satu hewan laut), tetapi digunakan untuk menyatakan 'seorang yang bodoh' atau 'keadaan seorang yang tidak berpengetahuan'.

Kekayaan makna yang terkandung di dalam satu atau dua kata yang digabungkan, sebenarnya terangkai di dalam konsep yang ada di dalam benak orang yang menyampaikan, dan orang yang mendengarkan atau menerima. Oleh karena bahasa dapat mengidentifikasi perilaku ataupun budaya masyarakat penggunanya, maka konsep-konsep yang melahirkan sejumlah makna itu bersumber dari keberadaan masyarakat dan lingkungannya.

Bentuk seperti contoh bahasa Indonesia itu, juga dikenal oleh penutur bahasa Kei. Bahasa ini merupakan sebuah bahasa daerah yang digunakan di Provinsi Maluku, tepatnya di Kepulauan Kei yang terdiri atas Pulau Kei Kecil, Pulau Kei Besar dan pulau-pulau sekitarnya. Istilah setempat untuk bahasa Kei adalah Veveu Evav. Dalam pengklasifikasian yang dilakukan para linguis, bahasa Kei atau Veveu Evav termasuk rumpun bahasa Austronesia (Taber, 1996: 87; SIL, $2006: 15)$.

Dalam bahasa Kei dikenal bentuk uun matan, seperti dalam kalimat berikut

\begin{tabular}{|l|c|c|c|c|c|c|}
\hline Nutun & riin & ni & uun & matan & rat & hal halin \\
\hline setiap & marga & memiliki & kepala & mata & raja & masing-masing \\
\hline \multicolumn{8}{|c|}{ 'Setiap marga memiliki pemimpinnya masing-masing' }
\end{tabular}

Bentuk uun matan memiliki arti 'pemimpin dalam suatu marga' (kelompok kekerabatan). Kata uun diartikan dalam bahasa Indonesia sebagai 'kepala', dan kata 
matan artinya 'mata'. Bentuk ini digunakan dalam sambutan-sambutan yang dibawakan oleh bapa raja Faan (orang kepercayaan masyarakat adat yang dipercayakan untuk menjadi pemimipin) dalam masyarakat Kei) atau yang mewakilinya. Misalnya, pada saat penjemputan tamu.

Selain bentuk uun matan adapula bentuk ai mas yang berarti 'harta'. Kata ai diartikan dalam bahasa Indonesia adalah 'kayu'. Kata mas diartikan sebagai 'logam yang berwarna kuning'. Kata kayu digunakan karena latar belakang kekayaan hutan di Desa Faan yang dijadikan material untuk menopang kehidupan sehari-sehari seperti untuk membuat kole-kole (perahu berukuran kecil), menangkap ikan, membangun rumah ataupun, sebagai kayu bakar untuk masak. Berikutnya, kata mas yang sama dengan kata emas dalam bahasa Indonesia, diidentikkan sebagai benda berharga dari logam yang dikenal oleh masyarakat Kei sebagai harta kawin berupa gelang tangan (aksesori) yang disebut gelang adat. Berdasarkan hal itu, mas dimaknai sebagai sesuatu yang bernilai tinggi. Bentuk ai mas biasanya digunakan ketika seorang tetangga melihat keberhasilan usaha tetangganya, yang bukan diukur dari penampilan diri, melainkan dari kepemilikan harta (rumah dan uang) serta usaha yang maju.

Sebagaimana kata $a i$ 'kayu' yang telah dijelaskan penggunaannya dengan berlatar kekayaan hutan kayu di Desa Faan, kata ini ada juga yang digabung dengan kata ngam yaitu 'sejenis ikan kecil' (ikan teri) menjadi bentuk ai ngam. Bentuk ini digunakan untuk menggambarkanpenyampaian khotbah seorang pastor kepada umatnya tentang hidup rukun dan religius. Ibarat ikan ngam yang hidup berdampingan satu sama lain, berkerumun, dan berhimpun menjadi satu memberi gambaran hidup bagi umat untuk harus rukun dan religius. Kerukunan tercermin dari tindakan dan perilaku umat yang hidup saling membantu dan menolong.

Tampak bahwa penggunaan idiom bahasa Kei di Desa Faan berpotensi memunculkan sejumlah bentuk dan makna yang khas. Ditambah lagi dengan frekuensi penggunaannya yang relatif tinggi di Desa Faan, yang memungkinkan terjaringnya data yang memadai maka idiom-idiom dalam masyarakat Kei, khususnya di Desa Faan memiliki daya tarik yang cukup kuat untuk diteliti lebih dalam. Oleh sebab itu, penelitian ini bertujuan untuk mendeskripsikan penggunaan idiom bahasa Kei dalam masyarakat Desa Faan, berdasarkan fungsi dan bentuknya.

Secara etimologis idiom berasal dari bahasa Yunani idios yang berarti 'khas, mandiri, khusus atau pribadi'. Oleh sebab itu, idiom merupakan pola-pola struktural yang menyimpang dari kaidah-kaidah bahasa yang umum, biasanya berbentuk frasa, sedangkan artinya tak akan diterangkan dengan cara logis atau gramatikal, bersama bertumpu kepada makna kata-kata yang membutuhkannya (Keraf, 2002 : 109).

Menurut Kridalaksana (2008 : 90) bahwa idiom merupakan konstruksi dari unsur-unsur yang saling pilih, masing-masing anggota memiliki makna yang ada cuma karena dengan lainnya. Konstruksi yang maknanya berlainan dengan makna 
gabungan makna anggota-angotanya. Contoh : kambing hitam dalam kalimat "dalam sejarah kebakaran itu hansip jadi kambing hitam padahal mereka tak tau apa-apa". Di sini makna kambing hitam dengan cara total tak sama bersama kambing ataupun hitam.

Djajasudarma (2013 : 20) beranggapan bahwa idiom terbentuk dari beberapa kata yang dikombinasi sedemikian rupa sehingga menghasilkan makna yang berlainan. Sebagian idiom merupakan bentuk beku (tidak berubah), artinya kombinasi kata-kata dalam idiom dalam bentuk tetap. Bentuk tersebut tidak dapat diubah berdasarkan kaidah sintaksis yang berlaku bagi suatu bahasa. Terkait dengan hal itu, Lyons (dalam http://www.gurupendidikan.co.id) mengemukakan bahwa idiom hanya dipergunakan pada kesempatan tertentu oleh penutur asli sebuah bahasa.

Sementara itu, Cowie (dalam Subroto, 2011 : 142) berpendapat, idiom pada mulanya merupakan suatu frase atau kelompok kata dengan arti yang bersifat literal. Pemakaian idiom dalam waktu lama yang diulang-ulang terjadinya sifat membeku pada frase/kelompok kata tersebut sehingga tercipta makna baru. Dengan demikian, idiom tersebut telah menjelma jadi leksikon yang baru.

Mengacu pada beberapa pandangan di atas, dapat dirangkum bahwa ciri-ciri idiom antara lain, (i) berbentuk kelompok kata atau frasa; (ii) memiliki makna yang khusus atau khas; (iii) memiliki kecenderungan untuk menyimpang dari makna leksikal atau makna denotatif.

Menurut jenisnya, idiom dibagi atas (i) idiom yang didasarkan pada keeratan unsur yang berkaitan dengan makna denotasi; dan (ii) idiom yang didasarkan pengelompokan kata (kategori). Dari segi keeratan unsur idiom terbagi atas idiom penuh dan idiom sebagian. Selanjutnya, dari segi pengelompokan kata (kategori) idiom terbagi atas (i) idiom dengan bagian tubuh; (ii) idiom dengan kata indera; (iii) idiom dengan warna; (iv) idiom dengan benda-benda alam; (v) idiom dengan nama binatang; (vi) idiom dengan bagian tumbuh-tumbuhan; (vii) idiom dengan kata bilangan.

Berkaitan dengan penggunaan idiom, pandangan Halliday (1992 : 20) yang dirujuk memperlihatkan secara sederhana bahwa konsep penggunaan itu dapat dipadankan dengan fungsi bahasa. Artinya, fungsi bahasa dapat dikatakan sebagai cara orang menggunakan bahasa mereka. Dalam keadaan yang rampat, pengertian fungsi bahasa adalah cara orang melakukan sesuatu dengan bahasa mereka; seperti cara bertutur dan menulis, mendengarkan dan membaca untuk mencapai sasaran dan tujuan komunikasi.

Bühler (dalam Halliday, 1992 : 21) mengemukakan tiga fungsi dasar bahasa, yaitu (i) fungsi ekspresif; (ii) fungsi konatif; dan (iii) fungsi representasional. Fungsi yang memperlihatkan korelasi antara lambing bahasa dengan hal yang diwakilinya atau penggunaan bahasa yang menggambarkan situasi tertentu adalah fungsi representasional. Fungsi tersebut sangat mirip dengan fungsi 
ekspresif. Selanjutnya, fungsi konatif menggambarkan penggunaan bahasa untuk mengajak atau mempengaruhi. Kerangka Bühler kemudian diubah dan dikembangkan ke arah yang berbeda oleh seorang pendidik bahasa Inggris, James Britton, yang mengusulkan kerangka fungsi bahasa transaksional, ekspresif, dan poetik. Bahasa transaksional adalah bahasa yang menekankan peran pelibat, sedangkan bahasa poetik peran penulis lebih banyak dibandingkan dengan peran yang lain (pembaca atau pendengar).

Oleh karena bahasa digunakan untuk berbagai kegiatan atau keperluan dalam kehidupan bermasyarakat, maka makna bahasa itu pun menjadi bermacam-macam dilihat dari segi atau pandangan yang berbeda. KBBI (2012: 864) mengartikan kata makna sebagai (i) arti; (ii) maksud pembicaraan atau penulis, (iii) pengertian yang diberikan kepada suatu bentuk kebahasaan. Odgen dan Richard (dalam Mulyana, 2008: 281) menyatakan bahwa makna muncul dari hubungan yang khusus dengan manusia. Jadi, makna tidak melekat pada kata-kata, tetapi makna kata-kata itu membangkitkan makna dalam pikiran seseorang.

Leech (dalam Chaer 2012 : 293) membagi makna menjadi makna konseptual dan makna asosiatif. Makna konseptual adalah makna yang dimiliki oleh sebuah leksem yang terlepas dari konteks atau asosiasi apa pun. Kata kuda memiliki makna konseptual 'sejenis binatang berkaki empat yang biasa dikendarai; dan kata rumah memiliki makna konseptual 'bangunan tempat tinggal manusia'. Jadi, makna konseptual sesungguhnya sama saja dengan makna leksikal, makna denotatif, dan makna referensial. Sebaliknya, makna asosiatif adalah makna yang dimiliki sebuah leksem atau kata berkenaan dengan adanya hubungan kata itu dengan sesuatu yang berada di luar bahasa. Misalnya, kata melati berasosiasi dengan sesuatu yang suci atau kesucian; kata merah berasosiasi dengan 'berani atau juga 'paham komunis'; dan kata buaya bersosiasi dengan 'jahat' atau juga 'kejahatan'. Makna asosiasi sebenarnya sama dengan lambang atau perlambangan (metafora) yang digunakan oleh masyarakat bahasa untuk menyatakan makna konsep lain yang mempunyai kemiripan dengan sifat, keadaan, atau ciri yang ada pada konsep asal kata atau leksem tersebut.

Stern (dalam Ullmann, 2007: 58) berkata,"Manusia tidak bisa lari dari kenyataan bahwa sesuatu kata tentu mengacu kepada suatu acuan tertentu, dan bukan kepada yang lain, dan bahwa karakteristik ini merupakan dasar kokoh semua komunikasi.". Artinya, tidak seorang pun dapat menolak pentingnya konteks dalam penentuan makna kata.

Menurut Malinowski konteks harus menembus ikatan-ikatan yang hanya bersifat kebahasaan dan harus diteruskan kepada analisis terhadap kondisi-kondisi umum yang memayungi ketika bahasa itu dituturkan. Bahkan setiap kata, tidak peduli betapa tepat dan pasti maknanya, akan menurunkan dari konteksnya suatu kepastian (makna) yang pada hakikatnya hanya dapat muncul dalam ujaran-ujaran yang spesifik (Ullmann, 2007 : 60-61). 
Dalam kehidupan sehari-hari, kata makna digunakan dalam berbagai bidang atau konteks pemakaian. Halliday dalam (Prawirasumantri, dkk. 1997 : 15-16) memberikan pandangannya bahwa sosiologi mengkaji bahasa sebagai fenomena sosial dan budaya karena bahasa merupakan unsur yang digunakan manusia sebagai bagian hidup yang menyertai berbagai aktivitasnya. Hubungan semantik dengan fenomena sosial dan budaya terjadi karena aspek sosial dan budaya berperan penting dalam menentukan bentuk, perkembangan, dan perubahan makna satuansatuan bahasa. Oleh karena itu, sistem semantik berperan penting dalam konteks sosiolinguistik.

\section{B. METODE PENELITIAN}

Penelitian ini bersifat deskriptif kualitatif dengan memanfaatkan pendekatan sosiosemantis. Dikatakan deskriptif kualitatif karena penelitian ini menghasilkan data deskriptif berupa kata-kata tertulis atau lisan dari orang-orang dan berperilaku yang dapat diamati (Moleong, 2017: 157), sedangkan pendekatan sosiosemantis digunakan untuk perpaduan antara sosiologi dan semantik. Semantik sebagai ilmu yang mengkaji tentang makna dan sosiologi sebagai ilmu yang mempelajari setiap gejala interaksi sosial, struktur sosial, dan proses-proses sosial. Dalam memerikan makna, pendekatan sosiosemantis menitikberatkan pandangannya pada fungsi dan penggunaan bahasa dalam konteks situasi tertentu sebagai bagian dari konteks yang lebih besar, yaitu konteks kultural masyarakat pemakai bahasa yang bersangkutan (Prawirasumantri, dkk., 1997 : 73).

Data penelitian ini adalah data verbal berupa kata-kata atau kelompok kata berupa idiom dalam bahasa Kei. Data-data tersebut bersumber dari tuturan atau kalimat masyarakat Desa Faan yang mengandung idiom bahasa Kei.

Dengan begitu, lokasi tempat penelitian ini dilangsungkan adalah Desa Faan yang terletak di wilayah Kecamatan Kei Kecil. Secara geografis, Desa Faan berbatasan dengan Desa Wearlilir di sebelah Utara, dengan Desa Sathean di sebelah Selatan, di sebelah Barat berbatasan dengan pertahanan Ohoi Debut, dan di sebelah Timur berbatasan dengan laut Faan. Jarak antara Desa Faan dengan kota Langgur sebagai Ibukota Kabupaten Maluku Tenggara lebih kurang $5 \mathrm{~km}$ sebagaimana yang tampak pada peta berikut. 


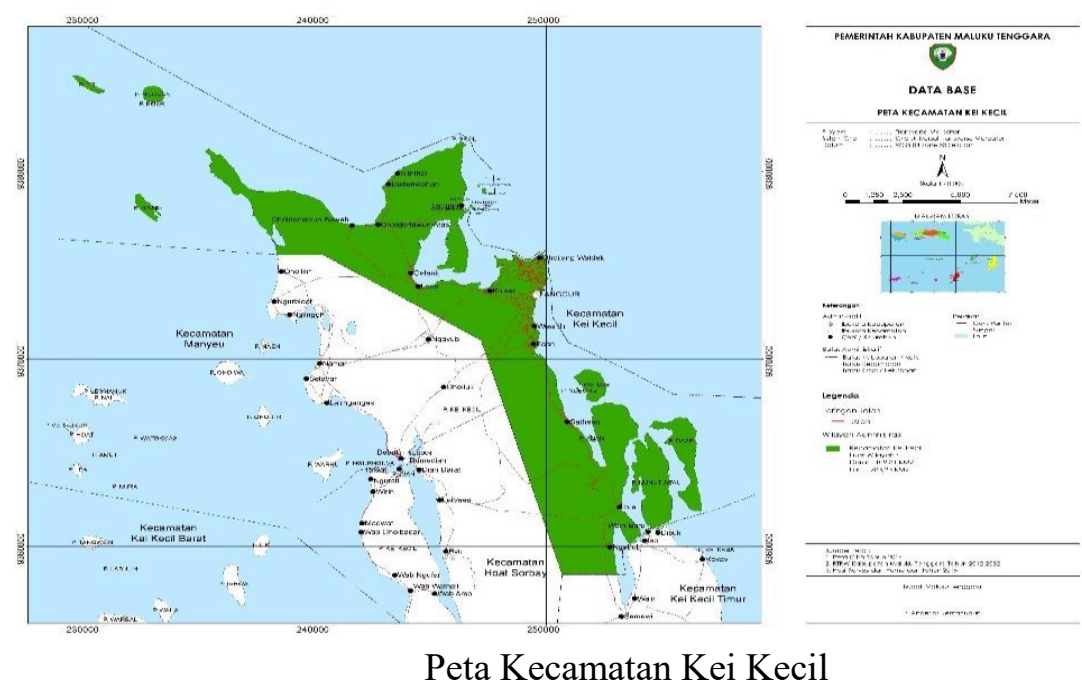

Keterangan:

O: Kota Langgur ( Pusat Keramaian Kota)

Desa Wearlilir

: Desa Faan (Lokasi Penelitian)

Laut Faan

: Desa Sathean

Desa Ibra (Bandar Udara Karel Sadsuitubun)

Untuk mengumpulkan data digunakan metode simak dengan teknik simak libat cakap (SLC), dan simak bebas libat cakap (SBLC). SLC adalah kegiatan mengambil data dengan ikut berpartisipasi dalam pembicaraan dan menyimak pembicaraan. Pada teknik ini penulis interaksi atau komunikasi yang berlangsung sekaligus sambil menyimak penggunaan bahasa yang digunakan oleh lawan bicara yang kemungkinan memunculkan idiom dalam bahasa Kei. Untuk teknik SBLC penulis tidak terlibat dalam dialog atau konversasi. Artinya, penulis tidak ikut serta dalam interaksi atau komunikasi yang berlangsung.

Metode wawancara yang digunakan penulis adalah wawancara terbuka atau mendalam, dan wawancara insidental. Wawancara insidental merupakan wawancara yang tidak sengaja dilakukan oleh peneliti (tidak direncanakan) sedangkan wawancara terbuka atau mendalam dilakukan dengan harapan ada informasi-informasi terkait lainnya yang dapat diperoleh untuk memperkaya analisis data.

Untuk mengecek keabsahan data, digunakan teknik triangulasi sumber, metode, teori. Dalam hal ini data-data berupa idiom yang diperoleh, dikonfirmasikan kembali antara seorang nasumber dengan narasumber yang lain, kemudian data-data yang diperoleh melalui metode-metode yang digunakan disandingkan lagi untuk mengecek kesesuaiannya. Berikutnya, data-data dicek 
lebih lanjut teori-teori yang digunakan bukan hanya untuk kepentingan keabsahan, melainkan juga untuk kepentingan pengklasifikasiannya.

Selanjutnya, penyajian data dilakukan dengan menerjermahkan masingmasing glos dari kata, frase dan kalimat agar mempermudah pembaca untuk memahami bentuk-bentuk idiom bahasa Kei, baik secara leksikal (kata per kata) maupun dalam pengertian seutuhnya yang penulis deskripsikan pada bagian pembahasan.

\section{PEMBAHASAN}

\section{Fungsi Representasional Idiom Bahasa Kei}

Menurut Karl Bühler dan Roman Jakobson (dalam Halliday, 1992 : 21) dikatakan bahwa:

\begin{tabular}{|l|c|c|c|}
\hline ndok & ken & tivun & mas \\
\hline duduk & tepat & pada & emas \\
\hline \multicolumn{4}{|c|}{ 'Lelaki memilih perempuan yang tepat' } \\
\hline
\end{tabular}

Idiom ndok ken tivun mas berfungsi secara representasional karena mas sebagai logam mulia atau barang berharga diidentikkan dengan seorang perempuan yang dinilai begitu berharga bagi kaum lelaki sehingga seorang laki-laki harus dapat memilih perempuan yang tepat sebagai pasangan hidupnya.

\begin{tabular}{|l|c|c|c|}
\hline bavov & enfok & hauk & nuhu \\
\hline kayu & hanyut & mencari & daratan \\
\hline \multicolumn{4}{|l}{ 'Pihak laki-laki mencari pihak perempuan' } \\
\hline
\end{tabular}

Pada idiom ini, kata bavov 'kayu' diidentikkan dengan seorang laki-laki, sedangkan nuhu 'daratan' diidentik dengan perempuan. Artinya, dalam kehidupan seharihari sepantasnyalah seorang laki-laki yang mencari perempuan sebagai pasangan hidupnya. Idiom ini sedang menegaskan bahwa hal sebaliknya sangat pantang dilakukan sebab terkait dengan idiom sebelumnya yang mengidentikkan perempuan sebagai mas; masyarakat Kei mendudukkan perempuan pada tempat yang terhormat. Dalam adat perkawinan di Desa Faan, idiom bavov enfok hauk nuhu ini selalu muncul untuk menggambarkan maksud kedatangan laki-laki untuk meminang perempuan yang dicintainya.

\begin{tabular}{|l|c|c|}
\hline vuut & aimehe & ngifun \\
\hline seekor ikan & menjadi & kantung ikan \\
\hline \multicolumn{2}{|l}{ 'satu keturunan' } \\
\hline
\end{tabular}

Idiom vuut aimmehe ngifun ini merepresentasikan kenyataan lain di luar pembicara dan lawan bicara, yakni satu jiwa atau seorang manusia yang dirujuk dengan kata vuut 
'seekor ikan' dan ngifun 'kantung ikan' yang merujuk pada keturunan yang banyak dari manusia yang semula hanya satu orang. Artinya, dalam satu kantung ikan dapat dihasilkan telur ikan yang tidak terbilang banyaknya. Pada waktunya nanti telur-telur itu akan menghasilkan ikan-ikan kecil dalam jumlah yang sangat banyak. Oleh sebab itu, masyarakat Desa Faan berpandangan bahwa satu jiwa dapat melahirkan keturunan yang banyak, dan mereka semua berasal dari satu keturunan.

\begin{tabular}{|c|c|}
\hline nibur & $\boldsymbol{u b}$ \\
\hline kerumunan & ikan julung \\
\hline 'menghormati dan bertoleransi' \\
\hline
\end{tabular}

Idiom nibur $u b$ menduduki fungsi representasional karena kata nibur yang makna leksikal atau makna denotasinya adalah 'kerumunan' merujuk pada kumpulan, sedangkan kata $u b$ yang makna leksikal atau denotasinya adalah 'ikan julung' (garfish) merujuk pada jenis ikan dengan mulut yang agak panjang. Kedua kata ini dirangkai dalam bentuk idiom untuk merepresentasikan kehidupan manusia yang tidak hanya hidup sendiri, tetapi harus berdampingan satu dengan yang lain. Representasi ini berangkat dari karakteristik ikan julung selalu berkerumun di dalam air. kehidupan yang berdampingan inilah yang menghadirkan sikap saling menghormati dan dapat bertoleransi dengan orang lain yang berbeda-beda latar belakang sosialnya. Sikap seperti ini akan sangat mudah untuk mewujudkan kehidupan yang rukun dan damai.

\section{Fungsi Konatif Idiom Bahasa Kei}

\begin{tabular}{|c|c|}
\hline uun & tew \\
\hline kepala & congklak \\
\hline \multicolumn{2}{|c|}{ 'seorang kepala atau pemimpin' } \\
\hline
\end{tabular}

Idiom uun tew mengarah pada fungsi konatif sehingga makna bahasa mengarah pada lawan bicara. Idiom uun tew dimaknai sebagai seseorang yang memiliki posisi yang strategis dalam kepemimpinannya. Idiom uun tew dapat ditujukan pada pemimpin-pemimpin yang kekuasaannya tinggi lebih khusus pada bapa raja. Oleh karena itu, sebagai bapa raja harus berfungsi dengan baik secara maksimal untuk kepentingan masyarakat adat. Kebijakan atau keputusan harus mempertimbangkan masyarakat adatnya. 


\begin{tabular}{|c|c|}
\hline envangvaik & yaf \\
\hline menyalakan & api \\
\hline 'bekal' \\
\hline
\end{tabular}

Idiom envangvaik yaf mengarah pada fungsi konatif karena mengarah pada mitra bicara. Idiom dimaknai sebagai 'bekal' tetapi memiliki maksud yang lebih dari sekadar bekal. Envangvaik yaf dimaksudkan untuk saudara perempuan yang menikah dan keluar dari Desa Faan, yang sedianya rumah tempat dia tinggal dapat menjadi persinggahan atau tumpangan bagi saudara-saudara sekampung yang mungkin dalam perjalanan yang jauh sehingga memerlukan persinggahan untuk beristirahat sejenak. Selain dapat beristirahat, diharapkan juga saudara perempuan dapat menyuguhkan makan dan minum ala kadar demi melepas dahaga dan lapar karena perjalanan jauh yang ditempuh. Dengan demikian, idiom envangvaik yaf sekaligus menjelaskan bahwa saudara perempuan asal Desa Faan yang telah menikah dan tinggal dengan suaminya tidak pernah memutuskan hubungan persaudaraan, tetapi dapat menjadi bekal pada saat dibutuhkan.

\section{Fungsi Poetik Idiom Bahasa Kei}

\begin{tabular}{|c|c|}
\hline laar & dit \\
\hline darah & menetes \\
\hline 'keturunan perempuan' \\
\hline
\end{tabular}

Idiom laar dit menduduki fungsi bahasa poetik karena bahasa yang poetik adalah bahasa yang terarah pada pesannya. Darah dan menetes dipakai untuk bentuk idiom karena merupakan sapaan untuk seorang perempuan yang menginjak usia remaja, gadis atau seorang dara. Seorang dara yang berpotensi untuk memperluas keturunan atau pancaran darah sehingga idiom ini memiliki pesan bahwa laar dit merupakan sapaan untuk menghormati dan menjunjung kaum perempuan sebagai penerus, pembawa, dan simpul dari aliran keturunan.Bentuk idiom laar dit ini dapat dijabarkan dalam tuturan kalimat berikut ini: Laar dit ni sa it hov did sa, korhel raskil it hov taskil yang artinya anak dara bersalah kita turut bersalah, anak laki-laki berbohong kita ikut dinilai. Maknanya kesalahan anak-anak 
turut kita dicemari dan kita mesti harus bertanggungjawab. Perilaku anak-anak turut mempengaruhi keluarga.

\begin{tabular}{|c|c|}
\hline ev & yanan \\
\hline pucuk & anak \\
\hline 'menghamili anak wanita' \\
\hline
\end{tabular}

Kata $e v$ yang artinya membuat besar makna merujuk pada perkembangan janin di dalam perut dan kata yanan atau anak artinya janin yang berkembang besar kemudian sudah melahirkan. Idiom ev yanan tidak lagi memiliki arti perkata tetapi makna sudah menyimpang dari kata pembentuknya sehingga maknanya menjadi menghamili wanita.

\section{Fungsi Metalingustik Idiom Bahasa Kei}

\begin{tabular}{|c|c|}
\hline $\boldsymbol{h i}$ & laai \\
\hline dia & besar \\
\hline \multicolumn{2}{|c|}{ 'orang terhormat' } \\
\hline
\end{tabular}

Idiom hi laai menduduki fungsi metalinguistik karena bahasanya terarah pada kodenya atau lambangnya. Hi laai bukan dilihat dari artinya dia besar yang diidentik dengan badan yang besar melainkan kepemimpinan yang baik sehingga disebut orang terhormat. Orang terhormat diidentik dengan orang yang mempunyai intelektual yang baik, kedudukan dan kekuasaan tertinggi dalam lembaga adat, lembaga pendidikan, lembaga kemasyarakatan. Birokrasi pemerintahan yang dipimpin oleh orang yang dipercayakan dapat memimpin masyarakatnya dapat disebut Hi laai. Bentuk hi laai menggunakan fungsi bahasa menurut Roman Jakobson yaitu fungsi metalinguistik.

\begin{tabular}{|c|c|}
\hline wod & lau \\
\hline ikan besar & kawanan \\
\hline \multicolumn{2}{|c|}{ hubungan darah' } \\
\hline
\end{tabular}

Idiom wod lau menduduki fungsi metalinguistik karena bahasanya terarah pada kodenya atau lambangnya. Wod lau dapat menjadi lambang untuk kita terlebih khusus masyarakat Desa Faan untuk dapat mengenal dari mana ia berasal. Kekerabatan yang terjalin antara marga satu dan marga lain yang melahirkan 
keturunan yang turun-turun dijaga dan dipelihara oleh setiap marga untuk mempeerat tali persaudaraan yang dibangun sejak keturunan pertama sampai keturunan dini. Oleh sebab itu, maka hubungan darah menjadi tanda bahwa ia mengenal asal usul dan mengetahui tentang adat yang diberikan turun temurun lewat orang tua dan leluhur. Bentuk wod lau menggunakan fungsi bahasa menurut Roman Jakobson yaitu fungsi metalinguistik.

Ikan besar dan kawanan sebagai ilustrasi dari makna kata hubungan darah. Kata ikan besar sebagai induk terpancarnya keturunan dan aliran darah yang mengalir dalam pribadi masing-masing orang sedangkan kawanan berarti keturunan yang dalam jumlah yang besar lebih dari satu ikan besar sebagai induk dari satu keturunan. Kedua kata ini lebih merujuk pada kehidupan manusia yang tidak hanya hidup sendiri tetapi berdampingan satu dengan yang lain. Manusia memiliki hubungan dengan manusia lain dikarenakan adanya pertalian darah dari nene moyang yang menjadi keturunan. Makna hubungan darah dapat jelas dipahami apabila terdapat dalam konteks tertentu.

\begin{tabular}{|c|c|}
\hline eak & ye \\
\hline ikat & kaki \\
\hline \multicolumn{2}{|c|}{ 'bertunangan' } \\
\hline
\end{tabular}

Idiom eak ye atau eak sit yahau welan menduduki fungsi metalinguistik karena bahasanya terarah pada kodenya atau lambangnya.

Kata eak ye sebenarnya memiliki kepanjangan dari kata eak sit yahau welan. Kata eak berarti mengikat dan kata ye berarti kaki. Kata mengingkat dalam adat perkawinan Kei sebagai cara bagaimana mengikat pemudi dan pemuda dalam ikatan sakral. Cara ini biasanya kedua mempelai diikat dengan mas adat atau seutas tali pengikat. Mas adat diberikan dari pihak pemuda kepada pihak pemudi. Sedangkan kata ye atau kaki sebagai tanda bahwa seorang pemudi telah diminang atau bertunangan sehingga pemudi yang diminang tidak dapat menjalin kasih dengan pemuda yang lain. Ungkapan ini memiliki maksud bahwa seorang pria memberi tanda kepada seorang perempuan yang dicintainya dengan sebuah mas adat, yang disebut mas eak ye. Ungkapan ini memiliki makna dalam masyarakat adat Kei bahwa keduanya menjadi calon atau bakal calon hidup bersama sebagai suami istri yang telah direstui oleh orang tua dan diterima dengan jalur adat.

\begin{tabular}{|c|c|}
\hline wis & \multicolumn{1}{c|}{$\boldsymbol{a}$} \\
\hline perbaiki & kerusuhan \\
\hline \multicolumn{2}{|c|}{ 'kapitan' atau 'kepala perang' } \\
\hline
\end{tabular}


Idiom wiska menduduki fungsi metalinguistik yang terarah pada kodenya atau lambangnya. Idiom wis $k a$ memiliki makna kapitan (kepala perang) tidak memiliki maksud sebagai kepala perang melainkan sebagai pengatur sistem pertahanan dan keamanan, sebagai pengawal dan benteng pertahanan. Jadi, kapitan melambangkan benteng pertahanan. Kapitan (kepala perang) tidak selamanya memiliki maksud kepala perang tetapi lebih dari itu kapitan menjalankan fungsinya sebagai pengatur sistem pertahanan suatu wilayah atau desa.

\section{KESIMPULAN}

Berdasarkan hasil analisis penggunaan idiom bahasa Kei pada ranah adat didapati bahwa idiom-idiom berfungsi secara representasional, konatif, poetik, dan metalinguistik. Fungsi-fungsi tersebut tertuang dalamdua bentuk, yaitu bentuk idiom penuh, dan idiom sebagian. Bentuk idiom penuh memanfaatkan nama bagian tubuh, nama benda-benda alam, nama tumbuh-tumbuhan, nama hewan, nama jenis ikan nama sifat, kata-kata kerja, juga benda-benda yang lain.

Bentuk-bentuk yang yang dimanfaatkan itu cenderung bersifat klise atau tetap sehingga tidak mudah diubah oleh adat bahasa. Oleh karena kekhasan makna itulah kurang berpotensi untuk digunakan pada ranah yang lain.

\section{DAFTAR PUSTAKA}

Chaer, Abdul. 2009. Pengantar Semantik Bahasa Indonesia. Jakarta: Rineka Cipta. Djajasudarma, Fatimah. 2013. Semantik: Relasi Makna Paradigmatik, Sintagmatik dan Derivasional. Jilid 2. Bandung: Refika Aditama.

Halliday, M.A.K. \& Hassan Shadily. 1992. Bahasa, Konteks, dan Teks. Yogyakarta: UGM Press.

Kamus Besar Bahasa Indonesia Pusat Bahasa. Edisi IV. 2012. Jakarta: Gramedia Pustaka Utama.

Keraf, Gorys. 2002. Diksi dan Gaya Bahasa. Jakarta: Gramedia Pustaka Utama.

Kridalaksana, H. 2008. Kamus Linguistik. Jakarta: Gramedia Pustaka Utama.

Moleong, Lexy. 2017. Metodologi Penelitian Kualitatif. Bandung: Remaja Rosdakarya.

Pendidikan Guru. 2010. Pengertian Idiom menurut Para Ahli. http://www.gurupendidikan.co.id). Diakses pada tanggal ..........

Prawirasumantri, Abud, dkk. 1997. Semantik Bahasa Indonesia. Jakarta: Departemen Pendidikan dan Kebudayaan, Proyek Penataran Guru SLTP Setara D-III.

Subroto, Edi. 2011. Pengantar Studi Semantik dan Pragmatik. Surakarta: Cakrawala Media. 
Penggunaan Idiom Bahasa Kei pada Ranah Adat oleh Masyarakat Desa Faan, Kecamatan Kei Kecil

Summer Institute of Linguistics (SIL) International. 2006. Bahasa-Bahasa di Indonesia. Jakarta.

Ullmann, Stephen. 2007. Pengantar Semantik. Terj. Sumarsono. Yogyakarta: Pustaka Pelajar. 
Penggunaan Idiom Bahasa Kei pada Ranah Adat oleh Masyarakat Desa Faan, Kecamatan Kei Kecil 